\title{
Mineral Trioxide Aggregate (MTA) in Dental Practice: A Review
}

\author{
Singh R* and Taluja MK \\ MDS Orthodontics, Private Practice, India
}

*Corresponding author: Rajveer Singh, MDS Orthodontics, Private Practice, Modern Dental Clinic, Nai Sadak, Amritsar-143001, Punjab, India, Tel: 8437112959; Email: rajveersingh78@ gmail.com

\section{Review Article}

Volume 5 Issue 2

Received Date: April 13, 2020

Published Date: June 17, 2020

DOI: $10.23880 /$ oajds-16000257

\section{Abstract}

Mineral Trioxide Aggregate is a calcium silicate based cement. It has remained a wide reaching material in endodontics. It demonstrated a strong biocompatible nature owing to the high $\mathrm{pH}$ and its ability to form hydroxyappatite. MTA material provides a better seal than traditional endodontic materials as observed in dye leakage, fluid filtration, protein leakage studies, and it has been recognized as a bioactive material. This article will review the history, composition, types of MTA, Physical properties, mechanism of action and clinical application.

Keywords: Biocompatible; Hydroxyappatite; Microleakage

Abbreviations: MTA: Mineral Trioxide Aggregate.

\section{Introduction}

Recently, with the development of materials that are not only biocompatible but also bio-inductive, the emphasis has shifted from mere preservation to regeneration of the remaining pulp tissue. One such material, which has shown immense potential for regeneration, is Mineral Trioxide Aggregate (MTA). It was introduced by Torabinejad M at Loma Linda University, California, USA in 1993 and was given approval for endodontic use by the U.S, Food and Drug administration in 1998 [1]. MTA is a powder consisting of Tricalcium Silicate, Dicalcium Silicate, Tricalcium Aluminate, Calcium Sulfate Dehydrate and Bismuth Oxide [1]. MTA is compositionally formulated to have physical properties, setting requirements and characteristics necessary for an ideal repair and medicament material. MTA with an excellent long term prognosis, relative ease at which it can be used and with numerous exciting clinical applications promises to be one of the most versatile materials of the century in the field of dentistry [2]. MTA has been used to manage many clinical problems, including successful pulp caps, pulpotomies, apexifications, root perforations repair (surgical and nonsurgical), and root end fillings [3]. Furthermore, its ability to stimulate cytokine release from bone cells has been demonstrated, indicating that it actively promotes hard tissue formation. In all cases, MTA allowed bone healing and elimination of clinical symptoms. MTA showed high clinical and radiographic success rates as a pulpotomy agent causing dentin bridge formation while simultaneously maintaining normal pulpal histology [4]. The aim was to develop a material to help eliminate communication between the interior and the exterior of the tooth.

\section{Composition}

MTA consist of fine hydrophilic particles of Tricalcium Silicate, Tricalcium Aluminate, Tricalcium Oxide and Bismuth Oxide. It is similar to Portland cement except for the absence of Bismuth Oxide in Portland cement. Bismuth Oxide (17$18 \%$ ) is added to improve the properties and radioopacity. The particles are smaller and uniform in size in MTA when compared to Portland cement.

MTA is available as white and grey. The two differ mainly in the amount of iron, aluminium and magnesium oxides. The white MTA lacks the alumino ferrite phase that imparts the grey color to grey MTA [5]. MTA is a fine hydrophilic powder available in single sachet of 1 gram. Premeasured water sachet for ease of use is also available. In 1999 Pro Root MTA (DentsplyTulsa Dental Specialities, Johnson City, $\mathrm{TN}$ ) was the first commercially available MTA product. Some commercially available MTA are Pro-root MTA, MTA Angelus, 
MTA Angelus Blanco (Solucoes Odontalogicas), MTA Bio (Solucoes Odontologicas).

\section{Setting Reaction of MTA}

Sluyk, et al. [6], Torabinejad, et al. [3] and Schmitt, et al. [7] advocated that the powder water ratio for MTA should be 3:1. Mixing can be done on a paper pad or glass slab with a plastic or metal spatula to achieve a putty like paste consistency. This mix should be covered with a moist cotton pellet to prevent dehydration of the mix. MTA has a ph of 10.2 immediately after mixing. By the end of $3 \mathrm{hrs}$, the ph increases to 12.5 similar to that of calcium hydroxide. Sluyk et al suggested that mixing time should be less than $4 \mathrm{~min}$ for MTA [6].

\section{Physical Properties}

The set MTA shows no sign of solubility. However, if more water is added during mixing, the solubility increases. Budig, et al. found that when set MTA was exposed to water, it releases calcium hydroxide which may be responsible for its cementogenesis, inducing property [8].

\section{Radiopacity}

Ding, et al. [9] and Shah, et al. [10] found that MTA has comparable radiodensity as zinc oxide eugenol and is less radio opaque than super EBA, IRM, gutta percha or amalgam. According to Torabinejad the mean radioopacity of MTA is $7.17 \mathrm{~mm}$ equivalent to the thickness of Aluminium, which is adequate to make it easy to visualize radiographically [5].

\section{Compressive Strength}

Torabinejad M, et al. [5] studied physical properties of MTA and found that compressive strength at $24 \mathrm{hrs} 40 \mathrm{MPa}$ and at 21 days $67.3 \mathrm{Mpa}$; and in comparison between GMTA (Grey MTA) and WMTA (White MTA) result showed that compressive strength of GMTA was greater than WMTA.

\section{Marginal Adaptation and Sealing Ability}

Bates, et al. [11] found that MTA is superior to other traditional root end filling materials. According to Shipper, et al. [12] and Torabinejad, et al. [13] explained that MTA has excellent sealing ability which may occur because MTA expands during setting reaction. In presence of moist environment sealing ability of MTA is enhanced due to the setting expansion so it has been suggested that a moistened cotton pellet should be placed in contact with MTA before placement of the permanent restoration. Volois, et al. [14] found that $4 \mathrm{~mm}$ thickness of MTA is sufficient to ensure a good sealing.

\section{Reaction with Other Dental Materials}

MTA does not react with or interfere with any other restorative material. GIC or composite resin, used as permanent filling material does not affect the setting of MTA when placed over it [15].

\section{Tissue Regeneration}

MTA is capable of activation of cementoblasts and production of cementum [2]. It consistently allows for the overgrowth of the cementum and also facilitates the regeneration of the periodontal ligament. MTA allows bone healing and eliminates clinical symptoms in many cases [4].

\section{Antibacterial and Antifungal Property}

Al Hezaimi, et al. [16] stated that MTA has antibacterial effect especially against Enteroccocus Faecalis and Streptococcus Sanguis. But, accordingly to Torabinejad, et al. [17], MTA showed no antimicrobial action against any of the anaerobes. Also, it did not show certain effects on facultative bacteria.

\section{Biocompatability}

The biocompatibility of MTA is similar to chemicallyinert titanium and greater than silver amalgam, Super EBA, and IRM. After setting, MTA produces crystalline calcium hydroxide called Portlandite. Portland cement and MTA are rich in calcium oxide and in the presence of water, it forms calcium hydroxide. Alkaline $\mathrm{pH}$ levels and calcium ions in the fluid surrounding, which is unfavourable for bacterial growth. Calcium silicate based cements are active biomaterials; that is, they have the ability to induce favourable response from the host tissue [18].

\section{Mineralization}

MTA, just like calcium hydroxide, induces dentin bridge formation [19]. Many investigators believe that the hard tissue bridge deposited next to MTA is because of the sealing property, biocompatibility, alkalinity and other properties associated with this material $[3,20]$. Holland, et al. [21] found calcite crystals nearest to the openings of the dentinal tubules close to MTA. They therorized that the Tricalcium Oxide in MTA reacts with tissue fluids to form Calcium Hydroxide, resulting in hard-tissue formation in a manner similar to that of Calcium Hydroxide. But the dentin bridge that is formed with MTA is faster, with good structural integrity and more complete than with Calcium Hydroxide [22]. MTA also proves to be better at stimulating reparative dentin formation and maintaining the integrity of the pulp [23]. 


\section{Open Access Journal of Dental Sciences}

\section{Mechanism of Action}

MTA when placed in direct contact with human tissues, releases calcium ions for cell proliferation and creates an antibacterial environment by its alkaline ph which modulates cytokine production and encourages migration and differentiation of hard tissue producing cells [18].

\section{Clinical Application}

MTA has been used to manage many clinical problems, including successful caps, pulpotomies, apexification, root perforations repairs (surgical and non-surgical) and root end fillings [3].

\section{Discussion}

The treatment of necrotic pulp in an immature root has always been a challenge to clinicians due to lack of an apical stop. This has been treated with long term calcium hydroxide therapy involving multiple visits where there is an increase in the fracture potential of the root involved. MTA has become an excellent alternative to these complications by creating a biocompatible apical plug in a single visit [24]. Several investigators have demonstrated the use of dentin apical plugs in non-surgical root canal therapy of mature permanent teeth. MTA is a material that is best suited as an apical plug in an in vivo dog model with open apices [12]. Pace et al reported 17 cases with necrotic pulp and immature apices in a 10 year study with success rate of $94 \%$ (only one failure). They used the "MTA apical plug technique" demonstrating it was suitable for the management of teeth with open apices and periapical lesions [25]. Mente, et al. in a long term cohort study, found that orthograde placement of MTA with apical plug technique is a promising treatment for open apices [26]. A study was done by Al-Kahtani in which he suggested placing a $5 \mathrm{~mm}$ thickness of MTA as an apical barrier for apexification. This is because it gives an excellent seal and provides sufficient material to prevent it from being displaced [27].

A study by Petrou, et al. demonstrated that nonresorbable materials like MTA offer clinical advantages for indirect pulp treatment in deep carious lesion. White MTA demonstrated the ability to induce the formation of a harder dentin and lower the bacteria presence after six months. The study suggests a high success rate of $90.3 \%$ and leaves more remaining demineralized dentin in deep carious lesion than calcium hydroxide. The time of follow-up is an important factor after indirect pulp capping material three months following treatment [28]. Pitt Ford et al were the investigators who used MTA for repair of furcal perforations. They showed that cementum was formed beneath MTA in most treated teeth converse to the teeth whose furcal perforation sites were repaired with amalgam [29]. Various studies done suggest that MTA produces best histologic results compared with other currently used perforation repair materials [6]. A root-end filling is performed in endodontics when an extraradicular surgical approach is needed to address endodontic pathology. Most cases treated surgically cannot be expected to be treated by orthograde conventional root canal methods because of complex anatomy. MTA has excellent physical sealing properties and a good biological seal is obtained by the proliferation of cells directly on cementum while healing. Once the apical $3 \mathrm{~mm}$ of the root has been resected, the canal system can be opened and cleaned with surgical ultrasonic tips to create the retro-preparation. It is dried and MTA is placed and condensed in that space to create the retro-an additional filling [24].

MTA stimulates new hard tissue formation and promotes pulp repair. MTA has been able to stimulate hard tissue formation after vital pulp therapy [5]. It was hypothesized in other studies also that a hard tissue bridge next to MTA may occur because of its excellent sealing properties $[3,30]$, biocompatibility [31], alkalinity [3,32], antimicrobial properties [5]. Another noteworthy point when using MTA is that it needs to cure completely before placing a definitive restorative restoration on the treated tooth. Therefore it is necessary to schedule 2 treatment appointments relatively close together: the first to perform the pulpotomy and place the MTA, and the second to complete the tooth restoration after the MTA has been cured [32]. Secondly, its high cost remains a limiting factor.

\section{Conclusion}

MTA is compositionally formulated to have physical properties, setting requirements and characteristics necessary for an ideal repair and a medicament material. MTA with an excellent long term prognosis, relative ease at which it can be used and with its numerous exciting clinical applications promises to be one of the most versatile materials of the century in the field of dentistry.

\section{References}

1. Torabinejad M, Watson TF, Pitt Ford TR (1993) Sealing ability of Mineral trioxide aggregate when used as a root end filling material. J Endod 19(12): 951-955.

2. Torabinejad M, Hong CY, Lee SJ, Monesef M, Pitt Ford TR (1995) Investigation of mineral trioxide aggregate for root end filling in dogs. J Endod 21(12): 603-608.

3. Torabinejad M, Chivian N (1999) Clinical applications of mineral trioxide aggregate. J Endod 25(3): 197-205.

4. Schwartz RS, Mauger M, Clemen DJ, Walker WA III 
(1999) Mineral trioxide aggregate: A new material for endodontics. J Am Dent Assoc 130(7): 967-975.

5. Torabinejad M, Hong CU, McDonald F, Pitt Ford TR (1995) Physical and chemical properties of a new root end filling material. J Endod 21(7): 349-353.

6. Sluyk SR, Moon PC, Hartwell GR (1998) Evaluation of setting properties and retention characteristics of Mineral Trioxide Aggregate when used as a furcation perforation repair material. J Endod 24(11): 768-771.

7. Schmitt D, Lee J, Bogen G (2001) Multifaceted use of ProRoot MTA root canal repair material. Pediatr Dent 23: 326-330.

8. Budig CG, Eleazer PD (2008) In vitro comparison of the setting of dry Pro-Root MTA by moisture absorbed through the root. J Endod 34(6): 712-714.

9. Ding SJ, Kao CT, Shie MY, Hung C, Huang TH (2008) The Physical and Cytological properties of white MTA mixed with $\mathrm{Na}_{2} \mathrm{HPO}_{4}$ as an accelerant. J Endod 34(6): 748-751.

10. Shah PM, Chong BS, Sidhu SK, Pitt Ford TR (1996) Radio opacity of potential root end filling materials. Oral Surg Oral Med Oral Pathol Oral Radiol Endod 81(4): 476-479.

11. Bates CF, Carnes DL, Del Rio CE (1996) Longitudinal sealing ability of mineral trioxide aggregate as a root end filling material. J Endod 22(11): 575-578.

12. Shipper G, Grossman ES, Botha AJ, Cleaton Jones PE (2004) Marginal adaptation of mineral trioxide aggregate (MTA) compared with amalgam as a root end filling material: A low vacuum (LV) versus high vacuum (HV) SEM study. Int Endod J 37(5): 325-336.

13. Torabinejad M, Smith PW, Kettering JD, Pitt Ford TR (1995) Comparative investigation of marginal adaptation of Mineral Trioxide aggregate and commonly used rootend filling materials. J Endod 21: 295-299.

14. Valois CR, Costa ED (2004) Influence of the thickness of mineral trioxide aggregate on sealing ability of root-end filling in vitro. Oral Surg Oral Med Oral Pathol Oral Radiol Endod 97(1): 108-111.

15. Nandini S, Ballal S, Kandaswamy D (2006) Influence of glass ionomer cement on the interface and setting reaction of mineral trioxide aggregate when used as a furcal repair material using laser Raman spectroscopic analysis. J Endod 33(2): 167-172.

16. Al-Hezaimi K, Al-Shalan TA, Naghshbandi J, Oglesby S, Simon JH, et al. (2006) Antibacterial effect of two mineral trioxide aggregate (MTA) Preparation against
Enterococcus Faecalis and Streptococcus Sanguis in vitro. J Endod 32(11): 1053-1056.

17. Torabinejad M, Hong CU, Pitt Ford TR, Kettering JD (1995) Antibacterial effects of some root end filling materials. J Endod 21(8): 403-406.

18. Macwan C, Deshpande A (2014) Mineral trioxide aggregate (MTA) in dentistry: A review of literature. J Oral Res. Rev 6(2): 71-74.

19. Myers K, Kaminski E, Miller (1996) The effects of mineral trioxide aggregate on the Dog Pulp. J Endod 22(4): 198.

20. Torabinejad M, Smith PW, Kettering JD, Pitt Ford TR (1995) Comparative investigation of marginal adaptation of Mineral Trioxide Aggregate and other commonly used root-end filling materials. J Endod 21(6): 295-299.

21. Holland R, de Souza V, Nery MJ, Otoboni Filho JA, Bernabe $\mathrm{PF}$, et al. (1999) Reaction of rat connective tissue to implanted dentin tubes filled with mineral trioxide aggregate or calcium hydroxide. J Endod 25(3): 161-166.

22. Faraco IM Jr, Holland R (2001) Response of the pulp of the dogs to capping with mineral trioxide aggregate or a calcium hydroxide cement. Dent Traumatol 17(4): 163166.

23. Domingeuz MS, Witherspoon DE, Gutmann JL, Opperman LA (2003) Histolgical and scanning electron microscopy assessment of various vital pulp-therapy materials. J Endod 29(5): 324-333.

24. Tawil PZ, Duggan DJ, Galicia JC (2015) MTA: A Clinical Review. Compend Contin Educ Dent 36 (4): 247-264.

25. Pace R, Giuliani V, Nieri M, Nasso L, Pagavino G (2014) Mineral Trioxide Aggregate as apical plug in teeth with necrotic pulp and immature apices: A 10 year case series. J Endod 40(8): 1250-1254.

26. Mente J, Leo $M$, Panagidis $D$, Ohle $M$, Scneider $S$, et al. (2013) Treatment Outcome of Mineral Trioxide Aggregate in open apex teeth. J Endod 39(1): 20-26.

27. Al Kahtani A, Shostad S, Schifferle R, Bhambhani S (2005) In-vitro evaluation of Microleakage of an Orthograde Apical Plug of Mineral Trioxide Aggregate in Permanent Teeth with simulated immature apices. J Endod 31(2): 117-119.

28. Petrou M, Alhamoui F, Welk A, Altarabulsi M, Alkizy M, et al. (2013) A Randomized Clinical Trial on the use of Medical Portland Cement, MTA and Calcium Hydroxide in Indirect Pulp Treatment. 18(5): 1383-1389. 
29. Pitt Ford TR, Torabinejad M, McKendry DJ, Hong CU, Kariyawasam SP (1995) Use of mineral trioxide aggregate for repair of furcal perforations. Oral Surg Oral Med Oral Pathol Oral Radiol Endod 79(6): 756-762.

30. Arruda RA, Cunha RS, Miguita KB, Silveira CF, De Martin AS, et al. (2012) Sealing ability of mineral trioxide aggregate (MTA) combined with distilled water, chlorhexidine, and doxycycline. J Oral Sci 54(3): 233-
239.

31. Chacko V, Kurikose S (2006) Human pulpal response to mineral trioxide aggregate (MTA): a histologic study. J Clin Pediatr Dent 30(3): 203-209.

32. Annamalai S, Mungara J (2010) Efficacy of mineral trioxide aggregate as an apical plug in non-vital young permanent teeth: preliminary results. J Clin Pediatr Dent 35(2): 149-155. 